\title{
A New Daily Federal Funds Rate Series and History of the Federal Funds Market, 1928-54
}

Sriya Anbil, Mark Carlson, Christopher Hanes, and David C. Wheelock

\begin{abstract}
This article describes the origins and development of the federal funds market from its inception in the 1920s to the early 1950s. We present a newly digitized daily data series on the federal funds rate from April 1928 through June 1954. We compare the behavior of the funds rate with other money market interest rates and the Federal Reserve discount rate. Our federal funds rate series will enhance the ability of researchers to study an eventful period in U.S. financial history and better understand how monetary policy was transmitted to banking and financial markets. For the 1920s-30s, our series is the best available measure of the overnight risk-free interest rate, better than the call money rate that many studies have used for this purpose. For the 1940s-50s, our series provides new information about the transition away from wartime interest rate pegs culminating in the 1951 Treasury-Federal Reserve Accord.
\end{abstract}

Federal Reserve Bank of St. Louis Review, First Quarter 2021, 103(1), pp. 45-70. https://doi.org/10.20955/r.103.45-70

\section{INTRODUCTION}

The federal funds rate is the interest rate charged on unsecured, mostly overnight loans of funds held by depository institutions and other entities in accounts at the Federal Reserve

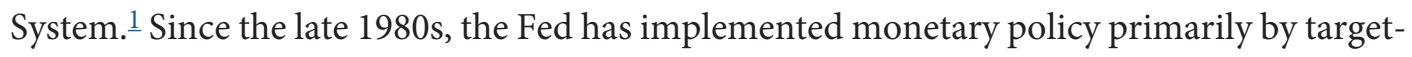
ing the federal funds rate. $\stackrel{2}{ }$ The Fed publishes the standard daily-frequency time series for the federal funds rate, which begins in July 1954. $\frac{3}{}$ However, the federal funds market came into being long before that, in the 1920s. This article introduces a new daily series for the federal funds rate that begins at the earliest possible date, April 1928, and continues to the start of the Fed's series. It is the first published time series of the federal funds rate at any frequency

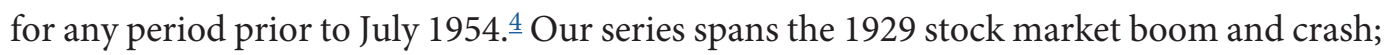

Sriya Anbil is a senior economist and Mark Carlson is a senior economic project manager in the Division of Monetary Affairs of the Board of Governors of the Federal Reserve System. Christopher Hanes is a professor of economics at the State University of New York, Binghamton. David C. Wheelock is a senior vice president and special policy advisor at the Federal Reserve Bank of St. Louis. The authors thank Jim Clouse, Kenneth Garbade, and Ed Nelson for comments on a previous draft of this article, and Qiuhan Sun, Arazi Lubis, and Elizabeth Getis for outstanding research assistance.

() 2021, Federal Reserve Bank of St. Louis. The views expressed in this article are those of the author(s) and do not necessarily reflect the views of the Federal Reserve System, the Board of Governors, or the regional Federal Reserve Banks. Articles may be reprinted, reproduced, published, distributed, displayed, and transmitted in their entirety if copyright notice, author name(s), and full citation are included. Abstracts, synopses, and other derivative works may be made only with prior written permission of the Federal Reserve Bank of St. Louis. 
the Great Depression; the years of recovery from the Great Depression during which, it is generally believed, short-term rates were at a zero lower bound; the period of interest rate ceilings imposed during World War II; and the lifting of the ceilings with the Treasury-Federal Reserve Accord of 1951. We believe that our series will prove useful for future research on American financial history, monetary policy, and macroeconomics.

The federal funds rate series published by the Fed is constructed from reports of federal funds transactions provided to the Fed. Our data come from New York City newspapers that reported on conditions and rates in American money markets. The New York Herald Tribune began regular daily publication of federal funds rate quotes in April 1928, observing that " $[\mathrm{M}]$ any students of the day-to-day fluctuations of money rates have turned to the current quotation for Federal Reserve funds as an indicator of the easiness or tightness of money.... [I] thas become a most important rate to be scanned for the information it reveals." $\underline{5}$ The Wall Street Journal began to publish daily federal funds rate quotes in June 1932. Our series relies on reports from both newspapers. $\underline{6}$

The appendix describes the construction of our series in detail. In the body of the article we present figures showing weekly average values of our series. We compare the federal funds rate with other money market rates and the Fed discount rate, era by era. To aid interpretation of our series we describe developments in the federal funds market from its origins through the 1950s and point out a few events apparent in our series that have largely escaped the attention of existing literature, including an upward move in the overnight rate off the lower bound in 1937 and a peculiar relationship between the federal funds rate and Treasury bill rates shortly after the end of World War II. We argue that our series is a better measure of the overnight, virtually risk-free interest rate than are other series that have been used for that purpose for pre-1954 periods, such as the stock exchange call loan rate, which has been widely used for the 1920s and early 1930s.

This article is organized as follows: Section 2 describes the overnight lending market in the United States before the founding of the Fed and origins of the federal funds market and provides an aside on the Fed's monetary policy strategy. Section 3 presents a weekly average of our daily funds rate series for 1928-33 and describes the evolution of the market in the context of the stock market boom of 1928-29 and early years of the Great Depression. Section 4 presents these data for 1933-39, a period that encompassed the recovery from the Depression; and Section 5 presents the data for 1940-54, which includes World War II and the early postwar years. Section 6 concludes. The appendix describes the sources from which we collected daily observations on the federal funds rate and how we calculated the weekly average series presented in the article.

\section{ORIGINS OF THE FEDERAL FUNDS MARKET}

Prior to the founding of the Fed, the United States already had an active overnight lending market in the form of "call money" (or "brokers") loans in New York City. ${ }^{7}$ Call money loans were collateralized by debt and equity securities, renewed day after day until the borrower

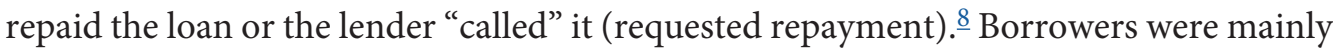


securities brokers and dealers in New York City who borrowed funds to finance inventories of securities or their customers' purchases of securities on margin. The immediate lenders were New York City banks, but the market was continental in scope as New York banks often acted as agents for other banks, businesses, and private individuals located elsewhere in the United States and Canada. Banks outside of New York also supplied funds to the call money market indirectly through the deposits they held in New York correspondent banks. Most call money loans were arranged on the floor of the New York Stock Exchange (NYSE), which at the time handled bonds as well as equities. Rates for call money loans on the NYSE floor were widely reported in newspapers and taken by contemporaries to be the best indicator of conditions in short-term money markets. ${ }^{9}$ Much economic research has relied on NYSE call money rate series to represent the safe short-term open market interest rate in the United States from the mid-nineteenth century through the early 1930s (e.g., Sylla ,1969; Officer, 1989; Rappoport and White, 1993; Odell and Weidenmier, 2004; and Fohlin, 2020).

In many ways, call money loans were similar to some of today's overnight lending instruments, such as "general collateral" repo. $\frac{10}{}$ Relative to those instruments, however, call money loans were peculiar in two ways. First, starting in 1914, the NYSE call money rate was set by stock exchange officials rather than in a competitive market, and sometimes the rate was deliberately set higher than a market clearing rate. 11 Second, the timing of call money loans was different. For today's overnight loans, the interest rates negotiated on a given day, and reported as prevailing on that day in financial publications and datasets, are paid on funds delivered by the close of that day to be repaid the following morning. For a call money loan, by contrast, the interest rate negotiated and reported to prevail on a given day was for funds delivered on the following day and repaid the day after that. The one-day lag occurred because call money loans were in "clearinghouse funds" - that is, funds to be paid through the New York Clearing House, which settled on a lagged schedule. 12

The Fed began to operate in November 1914. It soon developed a telegraphic network through which a bank with a Fed account could order an immediate transfer of funds to the Fed account of another bank anywhere in the system. $\frac{13}{}$ This made it possible to lend "federal funds" - that is, funds on deposit at Federal Reserve Banks, nationwide on an overnight schedule.

The first federal funds loans were made between New York City banks in the summer of 1921, as banks anticipating shortfalls in their Fed accounts entered into agreements to acquire funds from banks with surplus balances in their Fed accounts. ${ }^{14}$ Most of these transactions were overnight loans, in which the lending bank either provided a draft on its Fed account to the borrowing bank or arranged with the Federal Reserve Bank of New York to transfer funds from its account to the account of the borrowing bank. Either way the funds would be in the borrower's account by the end of the same day. In return, the borrowing bank would issue a cashier's check for principal and interest to the lender drawn on clearinghouse funds. The lender sent the check to the clearinghouse by the end of that day and received payment in the following day's clearinghouse settlement. $\frac{15}{}$

By 1925, banks outside New York City were lending federal funds locally. Lending between banks in different Fed districts was common by the end of the 1920 s. $\frac{16}{}$ Other participants in 
the market were dealers in bankers' acceptances and government securities (known in the 1920 s as "discount houses"). 17 These firms received payments in federal funds when they sold acceptances or government securities to Federal Reserve Banks and needed to make payments in federal funds for some of their purchases. Some firms maintained "nonmember clearing accounts" at the Fed and transferred federal funds through reserve accounts of Fed member banks with which they had relationships. Several discount houses became active borrowers and lenders of federal funds, and some became federal funds brokers, facilitating loans between others. In April 1928, the New York Herald Tribune reported that the leading brokers were "four or five of the larger discount houses" and that "for the nominal charge of $1 / 4$ of one percent...these houses locate banks which are in need of the excess balances of other institutions. Conversely they locate prospective borrowers for banks which are faced with a plethora of excess deposits at the [Federal] Reserve Bank." 18 Federal funds trading grew from a daily volume that rarely exceeded $\$ 20$ million in 1921 to one that averaged $\$ 40$ to $\$ 80$ million by 1925 and that after 1925 "ranged upward from \$100 million, reaching \$250 million at times." 19

Although the federal funds market grew in size over time, market volume remained small relative to other money market instruments throughout the 1920 s. $\stackrel{20}{ }$ Fed policymakers appear to have paid little attention to the federal funds market, or perhaps took it for granted. Two of the Fed's leading economists at the time, Burgess (1936) and Riefler (1930), hardly mention the federal funds market in their discussions of the money market and Fed policy. Nonetheless, the market was an important source of liquidity and a barometer of overall money market conditions. According to Willis (1970, pp. 12-13), "The chief function of the funds market was refining the reserve adjustment process of the unit banking system.... It improved the fluidity of the money market by bringing demand and supply into more rapid adjustment." The market was also acutely sensitive to Fed policy rates and actions. Differences in discount rates among the 12 Reserve Banks, which generated interregional flows of funds, could affect trading in the market. $\underline{21}$ The Fed's open market operations directly affected the supply of bank reserves and thus affected the funds rate. According to Willis (1970, p. 13), the funds rate "tended to be more sensitive [than other money market rates] and anticipate changes in bank reserve positions and factors affecting them because the use of funds offered an alternative to borrowing at the Reserve Banks."

\section{Federal Reserve Monetary Policy Strategy in the 1920s-30s}

Here we briefly describe the Fed's monetary policy strategy at the time and how it relates to supply of reserves. The origins of Fed monetary policy trace back to the "discovery" of open market operations in the early 1920s when Fed officials observed that their purchases of Treasury securities in the open market tended to ease money market conditions, lower interest rates, and increase bank lending (Chandler, 1958; Friedman and Schwartz, 1963; and Meltzer, 2003). By the early 1920s, System operations were carried out by the New York Fed as directed by a committee headed by that Reserve Bank's Governor, Benjamin Strong. Strong explained the Fed's policy strategy as follows:

The influence that the Reserve System exercises in the money market may be described... in this way: If speculation arises, prices are rising, and possibly other considerations 
move the Reserve Banks to tighten up a bit on the use of their credit.... [I]t is a more effective program...to begin to sell our government securities. It lays the foundation for an advance in our discount rate.... If the reverse conditions appear...then the purchase of securities eases the money market and permits the reduction of our discount rate. $\underline{22}$

Strong's description of the Fed's influence on money markets and bank lending was expanded upon by long-time Fed officials Winfield Riefler (1930) and W. Randolph Burgess (1936), which Meltzer (2003) refers to as the Riefler-Burgess Doctrine. Burgess (1936, p. 235) describes the impact of Fed open market operations as follows: "The Reserve Bank purchasing the securities pays for them with Federal Reserve funds. The seller of the securities deposits the funds in his own bank, and that bank in turn deposits the funds in the Federal Reserve Bank and thus finds itself in the possession of additional [nonborrowed] reserves...." The increase in bank reserves, reflected in a greater volume of deposits held in Fed accounts, increased banks' willingness to lend in the federal funds and call loan markets, as well as purchase securities and make longer-term loans.

Fed officials viewed the impact of open market operations on money markets as being heavily determined by the level of borrowing from the Fed's discount window (i.e., borrowed reserves). According to Burgess (1936, p. 239), "Purchases of securities by Reserve Banks tend to relieve member banks from debt to the Reserve Banks, and lead them to adopt a more liberal lending and investing policy. Money rates become easier.... Conversely, sales of securities by the Reserve Banks increase member bank borrowing... Money rates grow firmer." Thus, by regulating the relative stocks of nonborrowed and borrowed reserves, open market operations could influence market interest rates and banks' willingness to make loans even if they did not alter total reserves. However, when banks are out of debt to the Fed, "The effects of operations... are more direct. At such times Federal Reserve purchases of securities increase [total] bank reserves." Similarly, Riefler (1930, p. 27) argues that "The volume of member bank indebtedness at the Reserve Banks...is one of the most important single monetary factors in the level of money rates, and that the prospect of increase or decrease in that indebtedness is one of the most important single factors in the rate outlook... It is this relationship apparently which has given to Reserve Bank operations in the open markets that peculiar efficacy for control over the money markets...." Moreover, he writes, "The whole open market policy of the Reserve Banks... assumes...that Reserve Bank funds paid out in buying securities will be used by member banks to repay borrowing at the Reserve Banks or to meet demands for funds which would otherwise be met by increased borrowing" (p. 125). The supposed reluctance of banks to borrow at the discount window was a key assumption behind the Fed's theory of how its open market operations affected money markets and one that Fed officials sought to reinforce through their administration of the discount window. By discouraging banks from borrowing at the discount window, either by increasing the discount rate or by refusing loans to continuous borrowers, the Fed could reinforce the impact of its open market operations and discount rate changes on the money markets. 
Figure 1

Federal Funds, Call Loan, and Fed Discount Rates, April 1928-April 1933

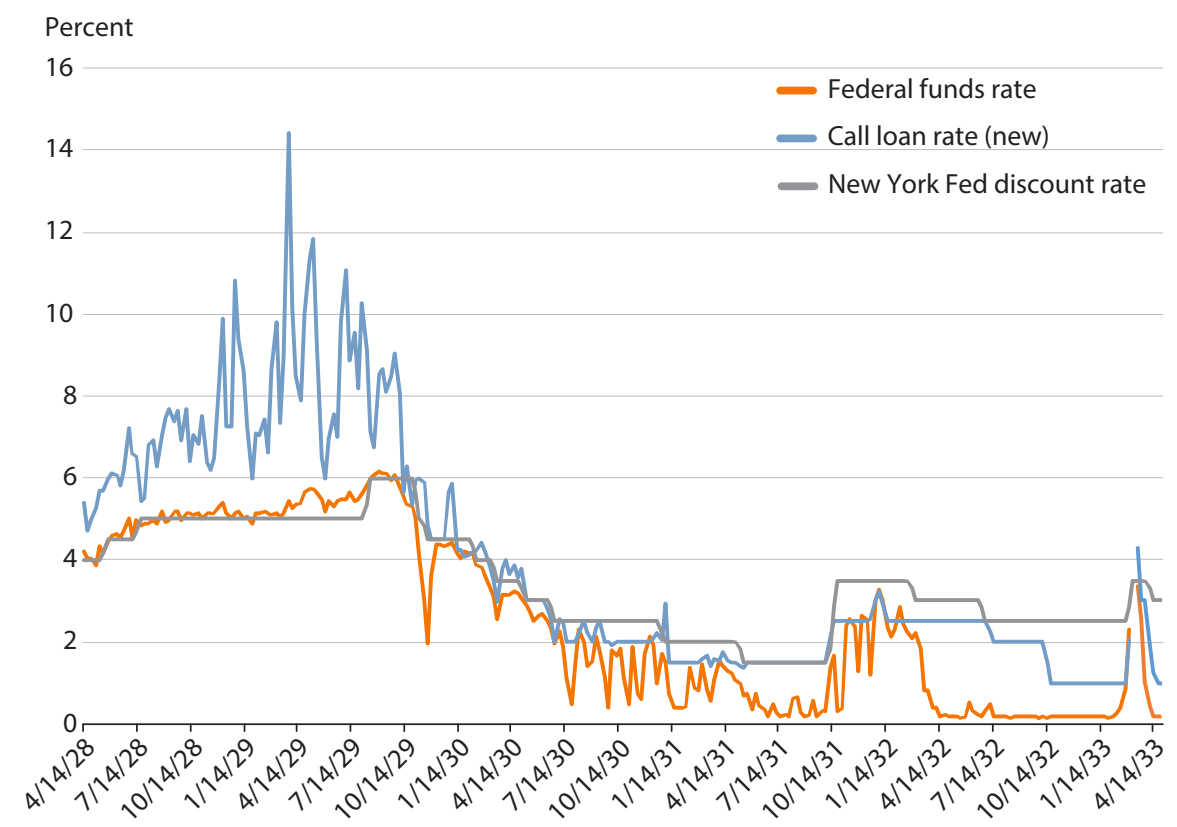

SOURCE: See "Other Data" section of the appendix and FRED ${ }^{\circledast}$, Federal Reserve Bank of St. Louis.

\section{THE FEDERAL FUNDS RATE, 1928-33}

Our new federal funds rate series is based on daily market quotations published in the New York Herald Tribune and Wall Street Journal. The appendix describes how we used the published quotes to produce daily and weekly (ending on Saturdays) average series for comparison with previously published weekly average rates for other money market instruments. The appendix also provides source information for the other series plotted in this article's figures.

Figure 1 plots the weekly average values of our federal funds rate series, the NYSE call money rate on new loans, and the discount rate of the New York Fed, from April 1928 (the start of our series) through April 1933, a month after the trough of the Great Depression according to the business cycle chronology of the National Bureau of Economic Research. The figure shows that the federal funds rate was nearly always below the call loan rate, presumably reflecting some combination of differences in default risk, transaction costs, and timing that made call money relatively undesirable for lenders active in both markets. $\underline{23}$

Figure 2 plots four-week rolling standard deviations of our weekly federal funds series and the call money rate on new loans. The figure shows that the call money rate was much more volatile than the federal funds rate before the 1929 stock market crash, suggesting that the call money rate behaved less like a virtually risk-free rate than did the federal funds rate, especially during a period when the perceived risk associated with call loan collateral was high (White, 1990). 


\section{Figure 2}

\section{Four-Week Rolling Standard Deviations of Federal Funds and Call Loan Rates}

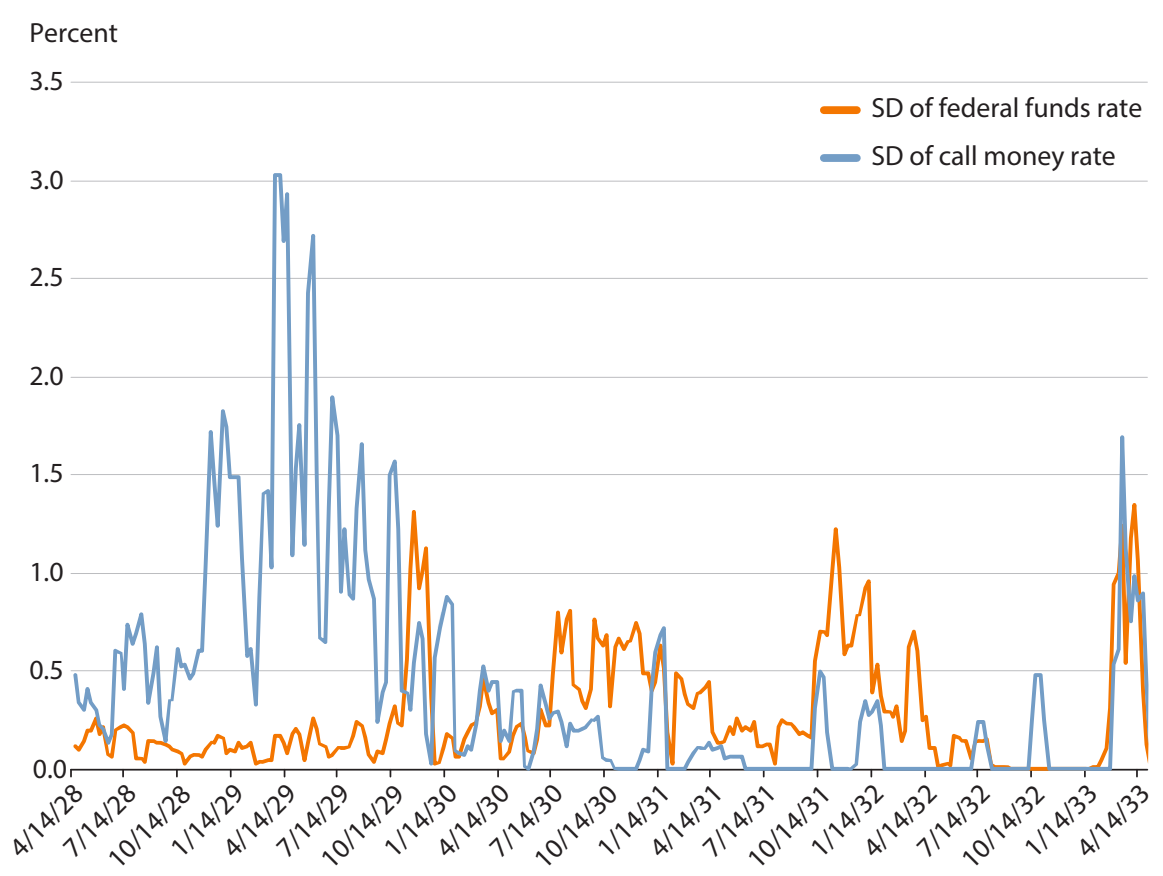

NOTE: SD, standard deviation.

SOURCE: See "Other Data" section of the appendix and FRED® , Federal Reserve Bank of St. Louis.

Figure 1 also shows the relationship between the federal funds rate and the New York Fed discount rate. Normally, the federal funds rate was at or below the discount rate, but the funds rate sometimes rose above the discount rate, especially when market conditions tightened. A borrower might be willing to pay more than the discount rate for federal funds because Federal Reserve Banks lent only to their member banks and only on specific types of collateralthat is, "eligible paper." $\underline{4}$ Thus, some institutions active in the federal funds market, such as nonmember banks and discount houses, did not have access to the Fed's discount window, while member banks might lack eligible paper. $\frac{25}{}$ Perhaps more importantly, the Fed did not lend freely even to member banks with eligible paper. In the 1920s, as in most of its later history, the Fed tried to dissuade banks from making continuous use of discount credit. According to Friedman and Schwartz (1963, pp. 268-69), this policy discouraged borrowing by "making discounting seem a source of weakness in banks." $\underline{26}$ The New York Herald Tribune (April 5, 1928 , p. 30) reported that the federal funds rate was "usually about one-fourth percent below the Federal Reserve discount rate" but could exceed the discount rate because "member banks are disinclined to borrow at the Reserve Bank, [with] continuous exercise of this privilege over extended periods being looked upon as an indication of weakness." The federal funds rate was especially high relative to the discount rate from February through August 1929, likely reflecting a Federal Reserve Board directive to Reserve Banks to deny discount window 
loans to banks that were making call money loans. The Board issued the directive in an effort to prevent the use of Fed credit to finance stock market speculation. $\underline{27}$

Rates on both federal funds and call money fell after the October 1929 stock market crash when the Fed purchased Treasury securities in open market operations, cut its discount rate, and allowed gold inflows from abroad to boost bank reserves. Whereas changes in the supply and demand for reserves caused the federal funds rate to fluctuate during 1930-31, as shown in Figure 1, the call money rate remained absolutely fixed across long spans of weeks. Further, the NYSE deliberately pegged the call money rate above the market clearing rate (e.g., Beckhart, 1932 , pp. 55, 58). Thus, the federal funds rate is almost certainly a better indicator of the true market overnight rate over these important years during the Great Depression.

The federal funds rate was at or close to the zero lower bound by mid-1931, but it increased sharply in late 1931 after the United Kingdom left the gold standard and the Fed raised its discount rate in an effort to discourage gold from flowing out of the United States. The funds rate then declined to the lower bound in early 1932 when the Fed boosted reserve supply substantially through purchases of Treasury securities (Friedman and Schwartz, 1963; Hsieh and Romer, 2006; and Bordo and Sinha, 2016). The call loan rate remained fixed at the crisis level until July, however, again reflecting the artificial setting of the rate. Both the federal funds and call loan rates spiked again during a banking crisis in March 1933, which culminated in a national bank holiday declared by President Roosevelt on March 6, 1933. Markets were closed for several days, resulting in gaps in both the federal funds and call loan rate series.

\section{Commercial Paper and Bankers' Acceptance Markets}

Figure 3 adds the prevailing interest rates on commercial paper and bankers' acceptances to the data shown in Figure 1 (omitting the New York Fed discount rate for clarity). Along with the call loan and federal funds markets, commercial paper and bankers' acceptances were the major private money market instruments of the 1920s and early 1930s. Whereas federal funds and call loans had a maturity of one day (though call loans were often rolled over), commercial paper and bankers' acceptances had longer maturities, typically from 90 days to six months.

In the 1920s-30s, the commercial paper market comprised short-term unsecured loans to moderately sized non-financial firms. (Most sources provide quotes for paper with either 90-day or four- to six-month maturity, suggesting they represented typical maturities.) Commercial paper dealers purchased short-term notes from issuing firms and then sold the paper to investors throughout the country. Banks were important buyers of commercial paper (Beckhart, 1932). In the secondary market, commercial paper interest rates reflected the credit quality of the firm issuing the paper. "Prime" commercial paper reflected paper considered by the National Credit Office (a private firm affiliated with the R.G. Dun credit rating agency) to be of the highest quality, and the secondary market interest rates on prime paper were used to construct the widely reported commercial paper rate. The commercial paper market was reasonably deep throughout much of the 1920s but was fading by the end of the decade, in part because other money market instruments had become more appealing to investors. Like all money markets, the commercial paper market largely dried up in the Great Depression. $\underline{28}$ 


\section{Figure 3}

\section{Federal Funds, Call Loan, Commercial Paper, and Bankers' Acceptance Rates}

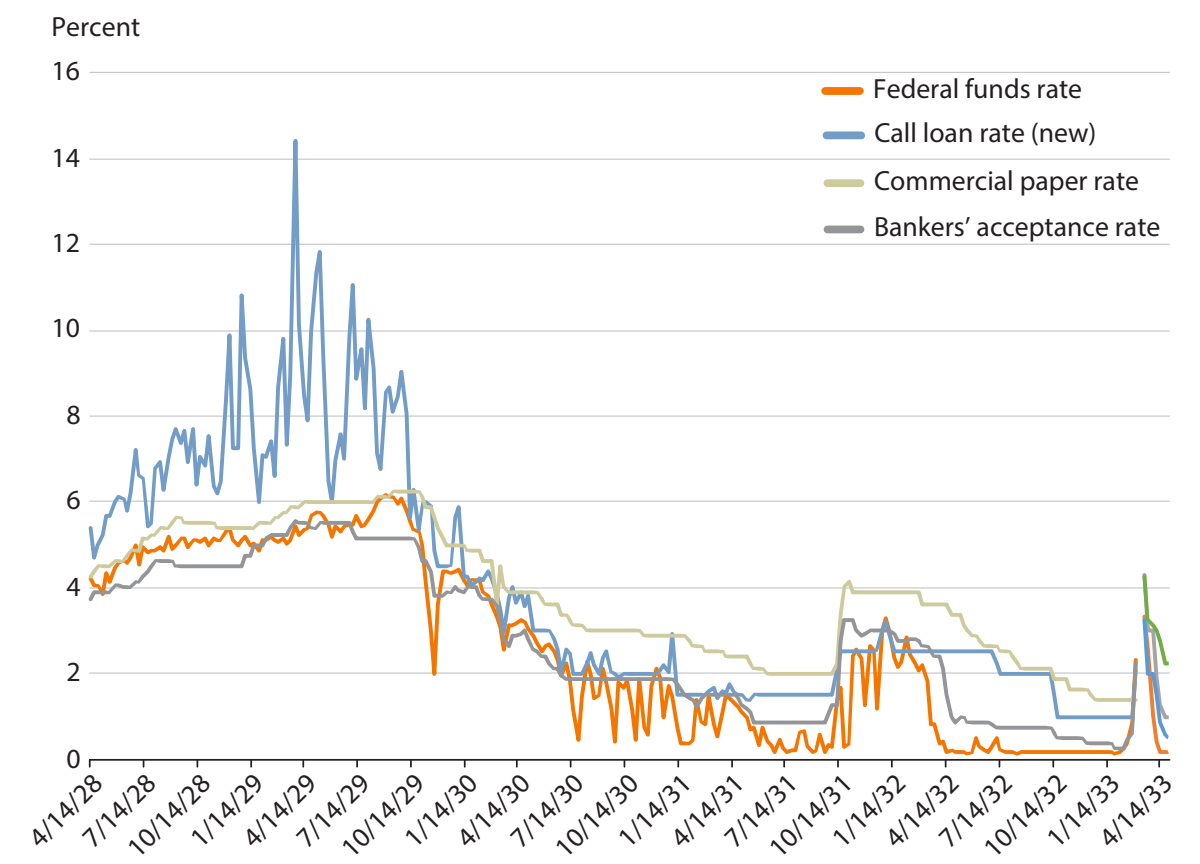

SOURCE: See "Other Data" section of the appendix and FRED ${ }^{\circledR}$, Federal Reserve Bank of St. Louis.

As Figure 3 shows, the commercial paper rate was typically higher than other money market rates, reflecting the longer average maturity of commercial paper and the absence of collateral backing. However, the commercial paper rate remained well below the call loan rate during the stock market boom in 1928-29.

Bankers' acceptances are private commercial payment contracts that are guaranteed by a bank; once guaranteed, the contract can be sold on the open market. A substantial portion of bankers' acceptances finance international trade. The bankers' acceptance market was very new in the United States in the 1920s, but it had been significant in other countries for many years. $\underline{29}$

From its inception, the Fed strongly supported the acceptance market. The Fed purchased acceptances (also referred to as "bills") at a rate that was advantageous to banks relative to borrowing from the discount window. The favorable terms resulted in the Fed holding 50 percent of outstanding acceptances at times during the 1920s. With this support, the market expanded rapidly. Because of the importance of Fed support, market rates on acceptances tended to track the buying rates set by the New York Fed..$\underline{30}$ As shown in Figure 3, the market rate on bankers' acceptances was consistently below the commercial paper rate. During 1928-29, the acceptance rate was also often below the federal funds rate. This likely reflected the Fed's tightening of monetary policy and attempts to discourage banks from using discount window 
loans to finance stock market speculation. Beginning in 1928, the Fed used open market sales to drain reserves from the banking system and increased its discount rates and bill buying rates. However, because policymakers continued to offer more favorable terms for purchases of acceptances, the interest rates on acceptances did not increase as much as those for call loans and federal funds. As with commercial paper, bankers' acceptance volume fell sharply during the Depression. The market rate on acceptances remained close to the Fed's buying rate, which remained at or above 1 percent throughout the Depression, even as the overnight rate on federal funds fell to less than $1 / 4$ percent. .11

\section{THE FEDERAL FUNDS RATE IN THE RECOVERY, 1933-39}

Figure 4 plots federal funds, NYSE call money (new loans), and New York Fed discount rates from May 1933 through December 1939. After the Bank Holiday, the New York Fed lowered its discount rate in a series of steps, from 3.5 percent to 1.5 percent in February 1934, and kept the rate at that level until 1937. The call money rate remained fixed at exactly 1 percent except for September-November 1933, when it was set at 3/4 percent, and several months in 1935-36 when the rate-setting committee, controlled by New York banks, experimented with rates of $1 / 4$ and $3 / 4$ percent. The lower rates "did not call forth any significant demand for funds" (Turner, 1938, p. 89) and, according to the banks, did not cover costs of handling

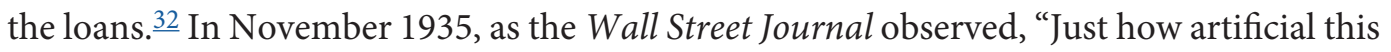
rate was is indicated by the fact that three months' money cost less than demand money all through this period. So long as the call money rate means nothing, the most interesting figures to watch in the short term money situation are the rates at which weekly Treasury bill issues are sold and the rates of inter-bank borrowings, or so-called Federal funds." $\underline{3}$

As suggested in the Wall Street Journal article, the federal funds rate behaved very differently than the call money rate. Between May 1933 and February 1934, the funds rate fluctuated between $1 / 8$ and $1 / 2$ percent. In late February 1934 it settled at 1/8 percent, where it remained for the next three years. On some days, newspapers reported that federal funds lending had occurred. $\underline{34}$ But the Wall Street Journal report for February 23, 1934, was more typical, stating "Federal funds offered by all banks, with no takers, at 1/8\%." Street Journal article observed that "With all the banks plentifully supplied with reserves, there is naturally no lending of reserve funds from bank to bank. The real condition of the money market is shown by the fact that the federal funds rate has been absolutely motionless since February 1934." 36 In January 1937, the New York Herald Tribune observed that "Federal funds have been available at $1 / 8$ percent for so long that hardly a man now exists in Wall Street who can remember when the rate was otherwise." $\underline{37}$

Demand for federal funds increased in March 1937 when the Fed imposed the second of a series of three increases in reserve requirements on member banks. At first a few, then most, transactions took place at a higher rate of $1 / 4$ percent. By May, when the third increase in reserve requirements took effect, some transactions were at 1/2 percent, which drew funds from banks outside New York. $\underline{38}$ Through August 1937 the funds rate ranged between 1/4 and $1 / 2$ percent. $\underline{39}$ Thereafter the reported rate was constant at $1 / 4$ percent through 1939 . Newspapers 


\section{Figure 4}

\section{Federal Funds, Call Loan, and Fed Discount Rates, May 1933-December 1939}

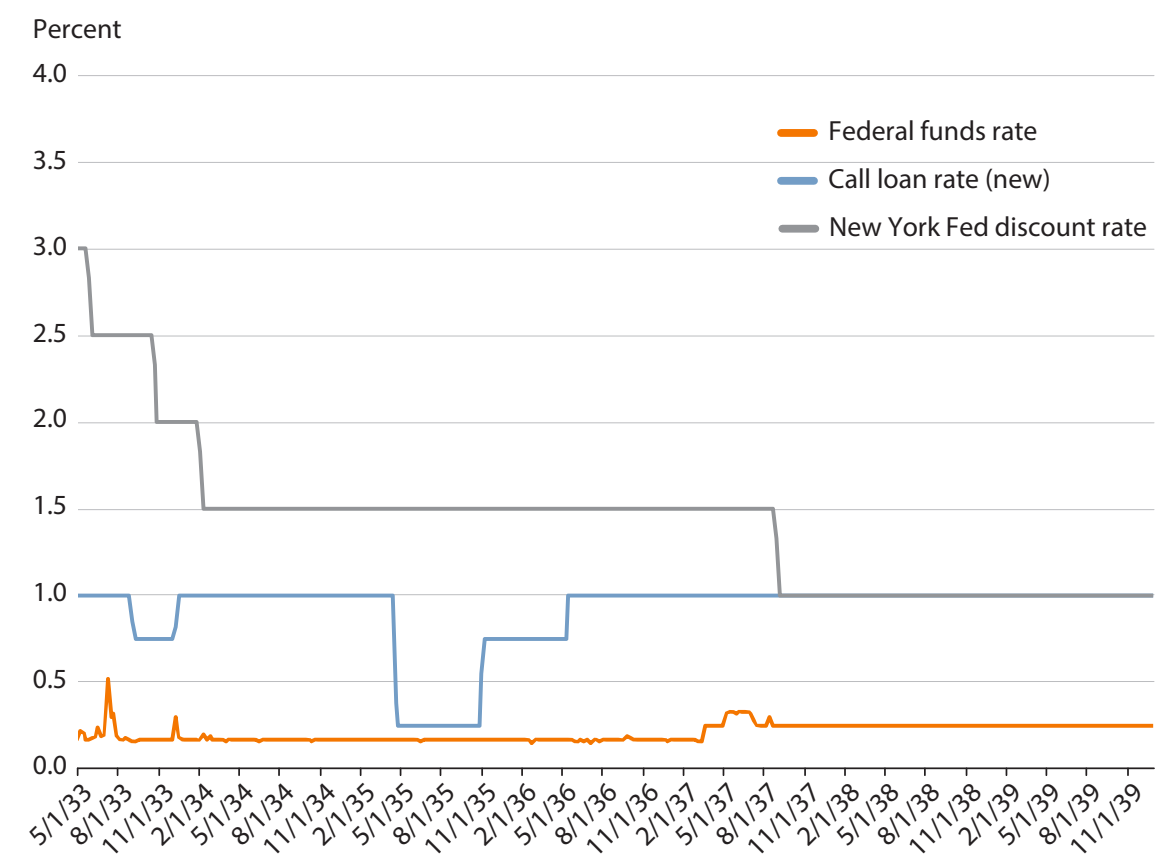

SOURCE: See "Other Data" section of the appendix and FRED® , Federal Reserve Bank of St. Louis.

continued daily publication of the federal funds rate but ceased to mention market activity apart from rare reports that borrowing had taken place. $\underline{\underline{40}}$

The combination of a flat rate with only occasional transactions from February 1934 to March 1937, and again after September 1937, suggests that the federal funds rate was at its lower bound most of the time. That is to say, the rate was so low that the interest payment on a loan minus the transaction costs to the lender was just marginally greater than the zero return to holding reserve balances. At a rate of $1 / 8$ percent, the interest payment on an overnight loan of $\$ 1$ million, a typical transaction in the 1920 s, was only about $\$ 3.50$. We have found no discussions dating from the 1930s about lenders' transaction costs. But in the 1950s, Minsky (1957, p. 175) observed that they include "the time of an officer, phone calls, etc." In a Fed study, some banks reported that even at an interest rate of $1 / 2$ percent, "costs absorb most of the return." $\underline{11}$ We have no explanation for why the lower bound was $1 / 8$ percent before 1937 , then $1 / 4$ percent after. $\underline{42}$

Standard models used to analyze overnight-rate determination and monetary policy implementation (e.g., Poole, 1968; Whitesell, 2006; and Ennis and Keister, 2008) can explain why the overnight rate was on the floor at these times. In those models the rate of return to holding excess reserves establishes a floor for the market overnight rate. The rate is driven to this floor when the supply of free reserves (i.e., nonborrowed reserves less required reserves, or equivalently, excess less borrowed reserves) is large enough to eliminate accidental reserve 
Figure 5

\section{Free Reserves and Discount Window Loans Outstanding}

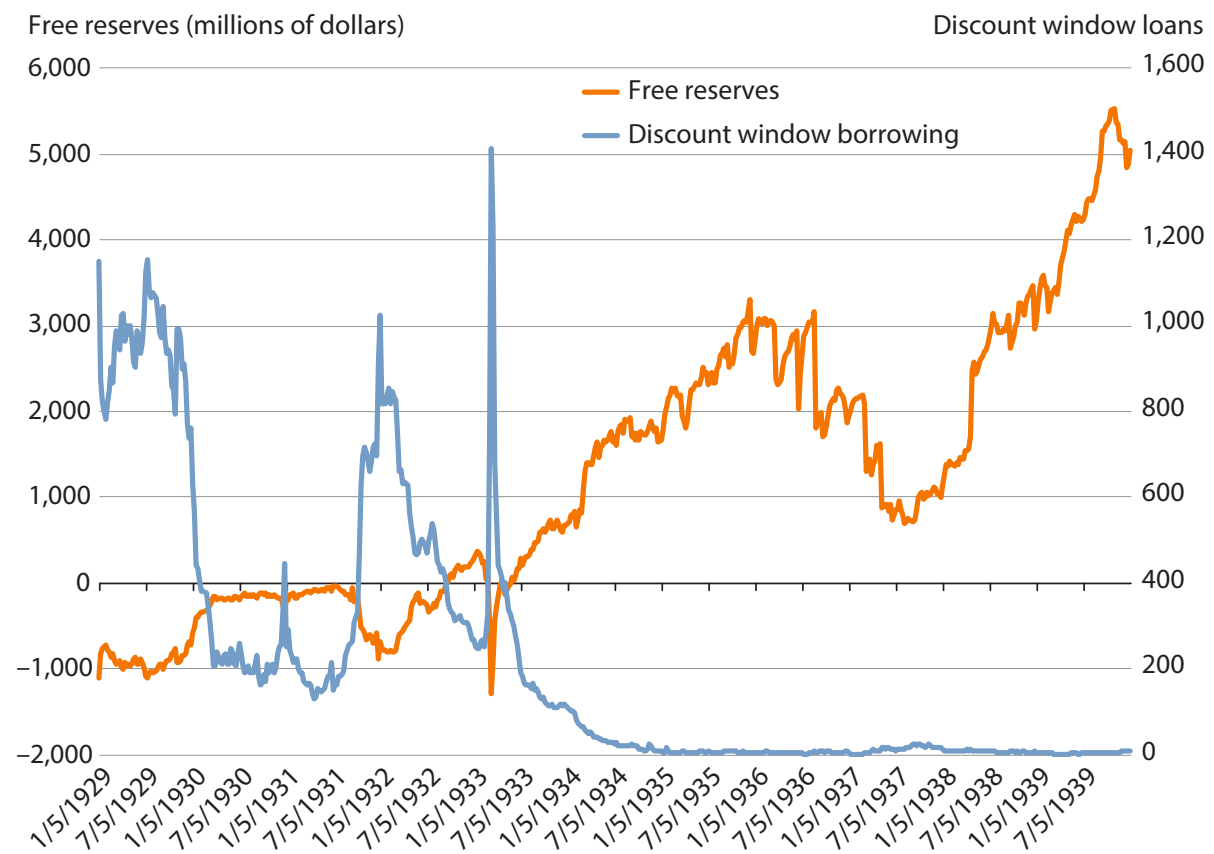

SOURCE: See "Other Data" section of the appendix and FRED ${ }^{\circledR}$, Federal Reserve Bank of St. Louis.

deficiencies. While this condition holds, banks largely cease to borrow from the discount window or in the federal funds market. Figure 5 plots free reserves and outstanding discount window credit from 1928 through 1939. The shock of the banking panic of March 1933 is evident in a sharp decline in free reserves that triggered a spike in borrowing at the discount window. Borrowing at the window fell to almost zero as the supply of free reserves rose from late 1934 through 1936, and again after 1937. A decline in free reserves in 1937 resulted in small increases in discount borrowing and the federal funds rate. The path of free reserves over time reflected interactions between Fed and Treasury policies on reserve requirements, open market operations, and international gold flows. $\underline{43}$

\section{THE FEDERAL FUNDS RATE IN THE 1940s AND EARLY 1950s}

Figure 6 plots the federal funds rate, the three-month Treasury bill rate, and the New York Fed discount rate from January 1940 to June 1954. The call money market did not revive after the war in the same form as it had existed before the war, and hence we do not include a call loan rate on the figure. ${ }^{44}$ From 1940 through March 1942, the Treasury bill rate fluctuated but the federal funds rate remained 1/4 percent. According to Willis (1970, p.15), a considerable volume of federal funds lending, "probably" $\$ 75$ to $\$ 125$ million per day, was taking place in early 1941. 


\section{Figure 6}

Federal Funds, Three-Month Treasury Bill, and Fed Discount Rates, 1940-54

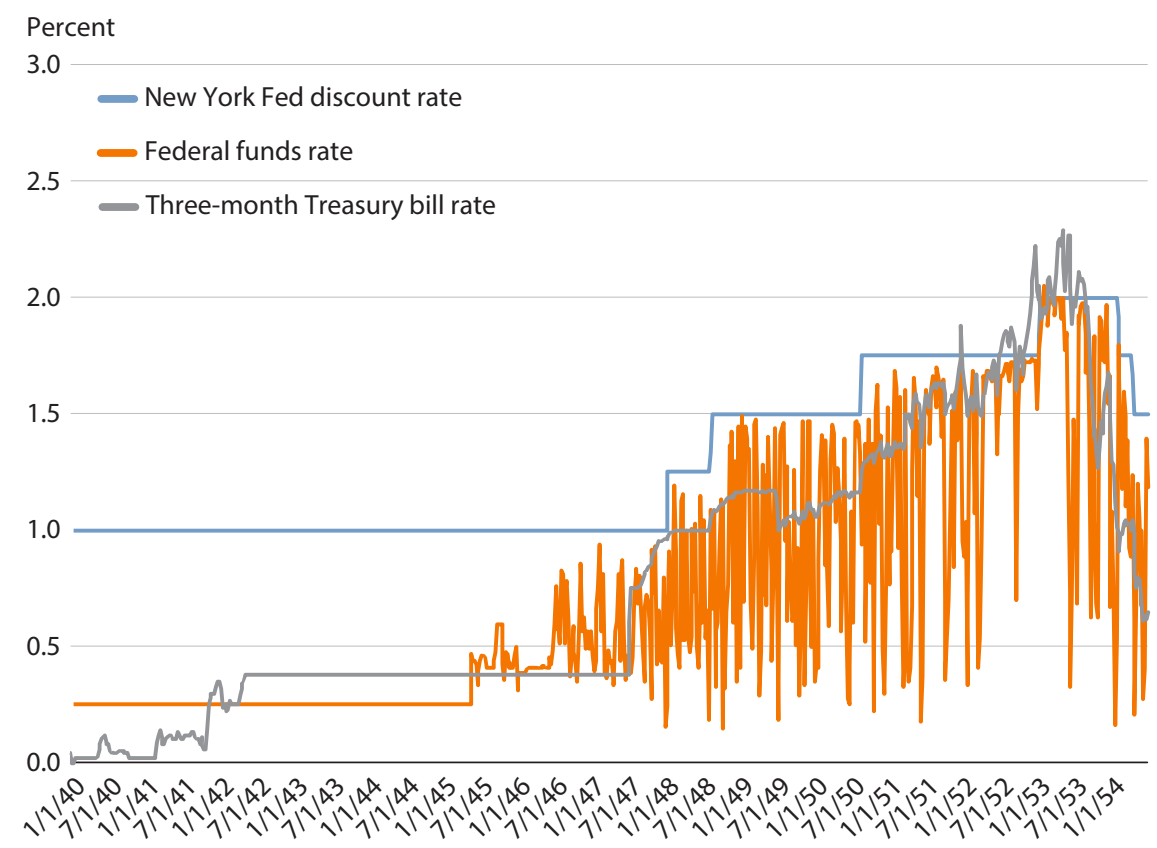

SOURCE: See "Other Data" section of the appendix and FRED ${ }^{\circledR}$, Federal Reserve Bank of St. Louis.

In April 1942, the Treasury and Fed agreed to keep interest rates on government securities low to finance the war. The Fed pledged to buy securities as needed to keep long-term Treasury yields from rising above $2 \frac{1}{2}$ percent and yields on shorter-term bonds, notes, and certificates below lower ceilings. The Fed maintained ceilings on these securities' yields throughout the war and afterward until the Treasury-Federal Reserve Accord of March 1951. $\underline{45}$

Fed policy with respect to Treasury bills is especially important as it had unique features that are key for understanding developments in money markets. In April 1942, the Board of Governors of the Federal Reserve System announced that it would buy bills at prices corresponding to an annual discount rate of $3 / 8$ percent. In August 1942, the Board gave anyone selling bills to the Fed the option to buy back "Treasury bills of a like amount and maturity" at the same 3/8 percent rate. This "enables banks and others, who have bought Treasury bills and encounter a temporary need for cash, to sell Treasury bills to a Reserve Bank with assurance that they will be able to repurchase the bills later at the same rate of discount." 46 In September 1942, the Board announced that payments associated with these transactions would be settled on the same day, rather than on the following day as previously, "to make the bills the equivalent of cash." 47

In the words of a contemporary, "The net result of these various provisions was to render Treasury bills absolutely liquid. They became practically equivalent to excess reserves and were so called and so treated by many bankers, even though legally they were not reserves at all" 
(Whittlesby, 1945, p. 67). The policies "had the effect, in substance, of enabling banks to earn interest on their excess reserves without undergoing the slightest sacrifice of liquidity" (p. 80). In modern terms, it was as if the Fed were paying $3 / 8$ percent interest on excess reserves. For nonbanks, bills had become equivalent to riskless overnight loans to the Fed, similar to transactions in the Fed's current Overnight Reverse Repurchase Program. $\underline{48}$

The Fed abandoned the Treasury bill program before it lifted ceilings on longer-term Treasuries after the 1951 Fed-Treasury Accord. In July 1947, the Federal Open Market Committee (FOMC) announced the "unpegging' of the Treasury bill rate.... [I]t had directed the Federal Reserve Banks to terminate the policy of buying all Treasury bills offered to them at a fixed rate of $3 / 8$ per cent per annum and to terminate the option given the sellers to repurchase bills.... The new policy was made applicable to new bills issued on or after July 10." $\underline{49}$ The pegging and unpegging of the Treasury bill rate is apparent in Figure 6.

The figure also shows that the quoted federal funds rate remained $1 / 4$ percent for the duration of the war but that the rate began to rise before the Fed removed the Treasury bill peg in 1947. Newspaper reports indicate that federal funds borrowing was extremely rare during the war. $\frac{50}{}$ In May 1945 the funds rate rose above 1/4 percent for the first time since August 1937. Remarkably, the rate immediately exceeded the $3 / 8$ percent Treasury bill rate, and it continued to exceed the bill rate in all but three weeks between May 1945 and July 1947, when the bill rate peg was ended. Thereafter, the bill rate sometimes exceeded the funds rate.

The patterns in rates suggest that before July 1947, the ability of lenders to earn a riskless overnight return of $3 / 8$ percent on bills prevented federal funds lending at a lower rate except in rare circumstances. The return of interest rate risk to the Treasury bill market and its impact on spreads between market rates on bills and the federal funds rate would have affected the preferences of banks for holding Treasury bills, especially as an instrument for managing their liquid reserves. The Board (1959, p. 10) noted this effect as follows: "The spread between bid and asked quotations and the risk of price change make the Treasury bill and other short-term securities unsuitable for very short-term reserve adjustments." In addition, “The increased fluctuation in bill rates in recent years has probably been more important than the comparative levels of rates in influencing choice between the bill and Federal funds markets. With day-to-day fluctuations in bill rates, a 'misguessed market' trend can lead to a principal loss on a quick bill turnaround-a loss which management can readily observe. An analogous error in the Federal funds market would simply mean a smaller return" (p. 71).

The revived federal funds market of the early postwar era was in some ways similar to the market of the 1920s. Loans between New York banks still involved an exchange in which the lender issued a draft on its Fed account and received a clearinghouse check from the borrower, while loans between banks in different cities went through the Fed's wire transfer service. $\underline{51}$ The difference between the timing of the federal funds settlement and the lagged settlement of clearinghouse funds was still important and motivated much federal funds market activity by nonbanks. $\underline{52}$

Nonetheless, there were also many differences between how the federal funds market operated in the post-war era and the 1920s. As shown in Figure 6, the federal funds rate did not rise above the discount rate as it had at times in the earlier era. To explain this, contem- 
poraries noted that banks now held large amounts of federal government debt and hence were never short of collateral for discount window loans. Moreover, discount borrowing was no longer hindered by a Fed policy to discourage call money lending as it had been in $1929 . \underline{53}$

After World War II, middlemen in the federal funds market also operated differently than they had before the war. Garvin Bantel Corporation was the only firm brokering federal funds from 1948 to 1958. It handled some 80 percent of all transactions through 1953 and 50 percent in 1957. $\underline{54}$ Many financial publications reported the rates quoted by Garvin Bantel as market rates. $\frac{55}{}$ According to the Board (1959, p. 5), Garvin Bantel did not charge a commission on federal funds transactions for banks that gave it some of their stock brokerage business: "A small percentage of the banks prefer to pay a flat fee, usually a commission of $1 / 16$ of 1 percent." If both the borrower and lender preferred to pay the flat fee, then Garvin Bantel earned $1 / 8$ percent, $\frac{56}{6}$ which was less than the typical $1 / 4$ percent spread charged for federal funds brokerage in the 1920s.

Aside from Garvin Bantel, government securities dealers helped banks place or obtain federal funds after the war (Federal Reserve Bank of New York, 1950). By convention, most transactions in Treasury securities were settled in federal funds (Board of Governors of the Federal Reserve System, 1959), so developments at government securities dealers had a notable influence on the federal funds market. Securities dealers commonly financed their inventories using overnight repurchase agreements, which were considered a segment of the federal funds market, not a separate instrument as they are today. $\underline{\underline{57}}$ Uncollateralized federal funds loans were then referred to as "straight" federal funds.

Several major banks also began to deal in federal funds, primarily by engaging in bilateral transactions with their respondents, which drew more small banks into the market. A second broker entered the market in December 1958, and by 1964, four firms acted as brokers in federal funds (Willis, 1970). As more brokers and trading banks entered the market, the minimum trade size declined, which allowed smaller banks to participate in the market (Meek, 1972), and volumes increased. The volume of transactions handled by brokers rose from a daily average of $\$ 100$ to $\$ 150$ million in 1949 , to $\$ 375$ to $\$ 425$ million in 1960 , and to $\$ 1,700$ to $\$ 2,800$ million in 1969 . $\underline{58}$ The high volatility of the federal funds rate clearly apparent in Figure 6 fell as market volume rose. $\underline{\underline{59}}$

\section{CONCLUSION}

Money markets are a vital part of the financial sector. Pricing and conditions in these markets provide a key indicator of liquidity in banking and financial markets generally. Money markets are also strongly influenced by monetary policy, and observing how these markets respond to changes in central bank policies are important for understanding how monetary policy is being transmitted to financial markets and the broader economy. The federal funds market is particularly valuable in both regards because of its intimate connection to the Fed and the banking system. By extending the rate data available for the federal funds market backward in time, we are providing valuable new information that researchers can use to understand monetary policy and banking sector liquidity in notable periods in U.S. financial history. 
The federal funds market originated in the early 1920s and developed as the Fed was learning to use the policy levers at its disposal in pursuit of macroeconomic, international, and financial stabilization goals. When our series begins in 1928, the Fed was moving to tighten monetary policy, first by conventional means and later by direct controls on discount window lending, in an effort to check stock market speculation. The federal funds rate reflected the impact of the Fed's actions on the money market, but without the confounding problems of trying to assess market conditions from the call loan rate. The federal funds rate (and other market rates) fell sharply after the October 1929 stock market crash, and the rate fell close to zero, well below the Fed's administered rates and the artificially set call loan rate. Market volume likely remained low throughout the Depression and World War II, but market rates rose with increased demand for reserves in banking crises in 1931 and 1933, and again in early 1937. Federal funds trading revived after World War II, even before the Fed ended its peg of Treasury bill rates in 1947. Our data reveal the impacts of the pegging and its end on money markets. Further, we show that, unlike the 1920s, the funds rate remained consistently at or below the Fed discount rate, possibly reflecting a change in the Fed's administration of the discount window.

Our new series on the federal funds rate ends in 1954 when a series reported by the Fed begins. The similar volatilities of our series and the Board's series in 1954 suggest that our series can be linked to the Board series and therefore provide researchers with a longer time series of high-frequency observations on the U.S. overnight interest rate. This article showcases these data over a pivotal era in U.S. monetary history, but it leaves for future research more formal analyses of the data and key episodes.

\section{APPENDIX}

\section{Federal Funds Rate Data}

Daily observations on the federal funds rate first appeared in the New York Herald Tribune on April 5, 1928, and in the Wall Street Journal on June 1, 1932. 60 We digitized the daily rates quoted in these publications from their first appearance through 1938 (New York Herald Tribune) and 1954 (Wall Street Journal), when daily federal funds rate observations become available from the Fed. These data are available in Federal Reserve Economic Data (FRED ${ }^{\circledR}, \underline{61}$ This section describes these data and how we used them to construct the weekly average series shown in the article's figures.

Both the New York Herald Tribune and Wall Street Journal published either a single rate or a range of rates for federal funds on each business day. The New York Herald Tribune reported rates for Monday-Saturday, beginning with April 4, 1928 (reported in the paper on April 5). However, the Wall Street Journal only reported rates for Monday-Friday. The New York Herald Tribune reported the prevailing rates for April 4, 1928, as “33/4@4” and indicated that the number to the left of @ was a bid rate and that the number to the right was an offered rate. $\underline{62}$ The New York Herald Tribune reported that the rates it published reflected quotes "by several of the largest discount houses." It continued to publish the rate in the same format in a table labeled "Money and Credit" throughout the 1930s. 
With very few exceptions, through mid-1931, the bid and offered rates published in the New York Herald Tribune always differed by $1 / 4$ of a point. Larger spreads were reported on a handful of dates, and negative spreads (i.e., a bid rate higher than the offered rate) were reported for four dates. $\frac{63}{}$ We suspect that the negative spreads, and probably some of the larger positive spreads, reflected printing errors. The dataset accompanying this article reproduces faithfully the rates as reported in the New York Herald Tribune. However, in constructing charts for the article, we omit observations with negative or implausible bid-offered spreads because we are unsure whether they reflected printing errors or something else. $\underline{64}$

Beginning in mid-1931, the rates reported in the New York Herald Tribune often differed by only $1 / 8$ of a point. These were always on days when the low and high rates were reported as $1 / 8$ and $1 / 4$, respectively. We are uncertain whether the smaller range reflects a narrowing of the bid-offered spread or a change in how the New York Herald Tribune reported the data. Turner (1931) reports that business was sometimes done on a 1/8 spread. However, on the first date that the Wall Street Journal reported funds rate information (June 2, 1932, p. 7), it reported that "Federal funds are in supply at $1 / 8$ to $1 / 4$ of $1 \%$." We presume that this quote refers to the range of rates that prevailed on June 1, which matches the range reported for that day in the New York Herald Tribune. Therefore, it seems plausible that by that date, the New York Herald Tribune was similarly reporting a range of rates that prevailed during the day rather than bid and offered rates. By early 1933, the Wall Street Journal started more clearly describing the price quotes as bid and offered rates. For example, on February 11, 1933, the Wall Street Journal reported "Federal funds firmer at 1/8\% bid, 1/4\% asked, with most trans-

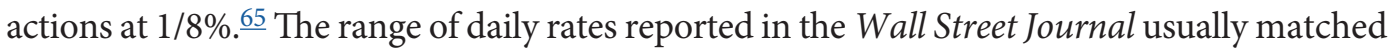
the range reported for the same days in the New York Herald Tribune. Occasionally the rates reported in the two publications differed, but almost never by more than $1 / 4$ of a point.

Whereas the New York Herald Tribune continued to report a range of rates on most days throughout the 1930s, the Wall Street Journal often published only a single rate, which it usually referred to as an offered rate. For example, on September 10, 1935, the Wall Street Journal reported that "Federal funds were freely offered and unchanged at 1/8\%." Usually when the Wall Street Journal reported just one rate, it was 1/8. For most such days, the New York Herald Tribune reported a spread of $1 / 8$ to $1 / 4$. Based on information about market conditions reported in the New York Times for many of those dates, we believe that the rate reported in the Wall Street Journal likely reflected the rate at which the preponderance of transactions occurred on the given day, if there were any transactions, whereas the rates reported in the New York Herald Tribune may have been quoted by dealers and not necessarily reflective of actual transactions. It seems likely that a rate of $1 / 8$ reflected the effective lower bound on offered rates due to transaction costs. We have no concrete information about the extent to which transactions occurred on days when the Wall Street Journal reported the rate at 1/8, though the New York Times sometimes indicates that funds were offered at 1/8 but that there was no demand.

Certainly, on some days the reported range of rates was not the bid-ask spread from dealers but rather the range of rates at which transactions took place that day. On May 4, 1937, a news article in the New York Herald Tribune reported that "As on Saturday...there was a 
split rate for Federal funds, with some funds placed at the old rate of $1 / 4$ of 1 percent and some at the firmer rate of $1 / 2$ of 1 percent. Banks in Chicago, Philadelphia and Boston were offering federal funds in this market [New York], for the most part at 1/4 of 1 per cent, for the other principal money centers were a little more comfortably situated than the local market was." The daily rate reported for these days, from which our series are constructed, was " $1 / 4$ @ 1/2." There was likely little trading in federal funds from mid-1933 through most of the remainder of the 1930s. With few exceptions, the Wall Street Journal reported the funds rate at 1/8 and the New York Herald Tribune reported a spread of 1/8 to 1/4 until March 1937, when market conditions tightened slightly following an increase in reserve requirements on Fed member banks. The Wall Street Journal subsequently reported a rate of $1 / 4$, and the New York Herald Tribune reported either a single rate of $1 / 4$ or a spread of $1 / 4$ to $1 / 2$. With only a couple of exceptions, both the Wall Street Journal and New York Herald Tribune reported a constant rate of $1 / 4$ throughout the remainder of the 1930s. $\frac{67}{}$

The Wall Street Journal continued to report the funds rate at $1 / 4$ percent through mid1945, after which there were signs of some pickup in activity. $\underline{6}$ On May 21, 1945, the Wall Street Journal reported an offered range of $3 / 8$ percent to $1 / 2$ percent. This reporting convention appears to have continued for several years; thus, in this period the reported high-low range reflects a different concept than the bid and offered rates from other dates. It is not until March 1948 that we observe the Wall Street Journal providing quotes for bids; and when bids are reported, they were reported as being within a range where there were no offers.

Starting in June 1948, the Wall Street Journal no longer reported ranges for bid and offered rates, but rather it listed single bid and offered rates. Nevertheless, both rates were not reported on some days. Indeed, even into the 1950s, there were days when the demand for funds appears to have fallen so much that the Wall Street Journal reported an offered rate but not a bid rate (and occasionally there were days when only a bid rate was reported). In these cases, we have left as missing the rate that is not reported.

\section{Weekly Average Funds Rate}

Using our daily data, we constructed weekly averages of the federal funds rate for comparison with other market rates, which are available in published sources as weekly averages. To calculate that weekly rate, we used the following procedure:

1. For days when both newspapers reported a high and a low rate, we calculate a daily average using observations from both newspapers as the simple average of the midpoints of the high and low rates reported in the New York Herald Tribune and Wall Street Journal. High and low rates were not necessarily bid and offered rates; on dates when the Wall Street Journal provided an offer range, our calculated rate is the midpoint of that range.

2. For days when one newspaper reported only a single rate, we take that rate as that newspaper's rate for the market and average it with the midpoint of the high and low rates provided by the other newspaper. 
Figure A1

Spread between Federal Funds Rate and New York Fed Discount Rate, 1954

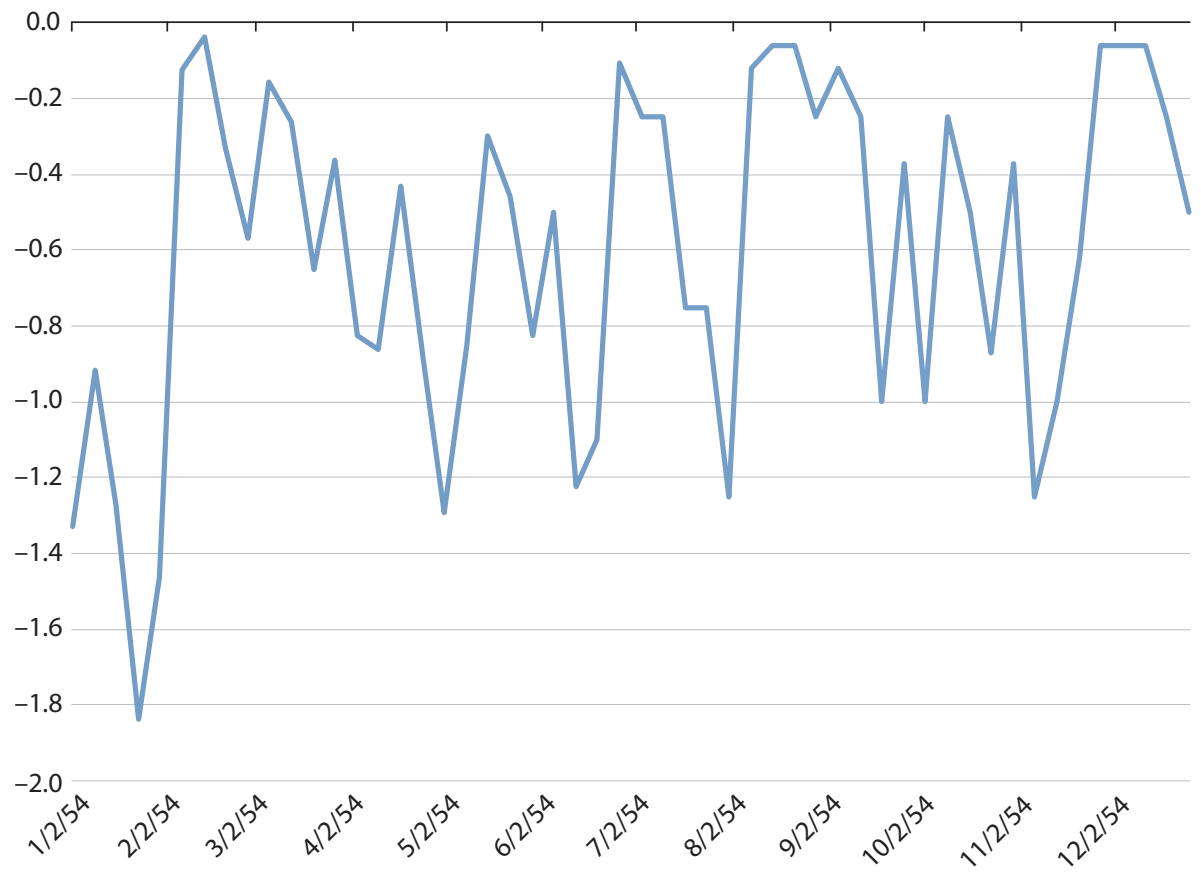

SOURCE: See "Other Data" section of the appendix and FRED ${ }^{\circledR}$, Federal Reserve Bank of St. Louis.

3. If only one newspaper provided data, we use the midpoint of rates or the single rate provided by that newspaper.

4. We omit dates when the spread between bid (low) and offered (high) rates reported in either publication is negative (i.e., bid higher than offered) and omit dates with implausible spreads (i.e., February 6, 1931, and June 20, 1931). The Wall Street Journal reported a rate of 1 percent on January 21 and 24, 1938, when the rate reported for surrounding days was 1/4 percent. Because the Wall Street Journal also reported that the rate for January 21 was "unchanged," for purposes of calculating the weekly average, we assumed a rate of $1 / 4$ percent for January 21 and 24 .

5. We use this daily series to calculate weekly average rates (Monday-Saturday) for the figures in this article.

\section{Linking our Federal Funds Rate Series with the Board Series}

As part of understanding the quality of our federal funds rate series, it is informative to compare it with the first few months of the federal funds rate series published by the Fed. Figure A1 plots the federal funds rate minus the New York Fed discount rate for 1954. Data for January-June are based on our newly constructed federal funds rate, and the data for JulyDecember are based on the Board's published rate data. The figure shows there is not an 
obvious discontinuity where our series links to the Board series. Both spreads fluctuate between 50 and 100 basis points throughout 1954 . Further, the volatility of the two series is roughly comparable around the transition point. The standard deviation of our series in the first half of 1954 is very similar to the standard deviation of the Fed series in the second half of 1954. Considering that the Fed began publishing the federal funds rate after the market revived, we consider the smooth transition between our series and the Fed series, with respect to both the level and standard deviation, as evidence of the validity of our series.

\section{Other Data}

Except as noted, the Board of Governors of the Federal Reserve System (1943) is the source for all data series other than the federal funds rate shown in the figures of this article, with the specific page numbers given below:

Bankers' acceptance rate (prime, 90 days), pp. 452-59

Call loan rate (average rate on new stock exchange loans), pp. 452-59

Commercial paper rate (prime, four to six months), pp. 452-59

Three-month Treasury bill rate, pp. 461-62 (1934-41); Board of Governors of the Federal Reserve System (1976), pp. 697-700 (1942-54)

Federal Reserve Bank of New York discount rate, pp. 439-42 (1928-41); Board of Governors of the Federal Reserve System (1976), p. 667 (1942-54)

Free reserves (excess reserves - borrowed reserves), pp. 378-9469

\section{NOTES}

1 In general, a federal funds transaction is an unsecured loan of U.S. dollars to a depository institution borrower (or "purchaser") from a lender (or "seller") that is another depository institution, foreign bank, government-sponsored enterprise, or other eligible entity; https://www.newyorkfed.org/aboutthefed/fedpoint/fed15.html.

$\underline{2}$ Since 2008 , the Fed has also used forward guidance and large-scale asset purchases in the conduct of monetary policy, particularly in periods when the federal funds rate target has been at the effective lower bound. In the 1970 s and 1980s, the FOMC set targets for various measures of reserves and monetary aggregates as well as for the funds rate; though with the exception of 1979-82, the federal funds rate target range was a primary component of the Committee's operating strategy. See Kliesen and Wheelock (2021) for more discussion about the FOMC's operating targets and methods in the 1970s and early 1980s.

$\underline{3}$ These data are available from FRED ${ }^{\oplus}$; https://fred.stlouisfed.org/series/FEDFUNDS. Current values of the Fed series on the "effective federal funds rate" are reported in the Fed's H.15 statistical release (https://www.federalreserve. gov/releases/h15/) and calculated as a volume-weighted median of overnight federal funds transactions reported by funds market brokers to the Fed; https://apps.newyorkfed.org/markets/autorates/fed\%20funds. Data reported by the Fed for 1954-70 are described in Board of Governors of the Federal Reserve System (1976, pp. 640-41) as follows: "The 'effective' rate on Federal funds is estimated each day by the Federal Reserve Bank of New York. It is not a statistical calculation, such as an average, of the rates paid on all transactions in Federal funds. Rather, it represents a consensus of major market participants in New York City as to the rate at which most transactions in these funds were executed during the day, after taking into account reports from active participants in the market. The data begin with the week ending July 14, 1954, when the Federal Reserve Bank of New York began to estimate the daily figure."

4 Willis (1957) includes a chart of a weekly federal funds rate series for the period we cover, based on data from one of the same sources, but the underlying data were not published. 
$\underline{5}$ New York Herald Tribune. "Federal Funds' Rate Index of Credit Status." April 5, 1928, p. 30.

6 The New York Times also reported federal funds rates on many but not all days.

7 See, for example, Myers (1931, pp. 126-48, 265-87).

$\underline{8}$ Legally, lenders could call a loan at any time of day; customarily they did so only in the morning. Usually the collateral was a basket of several stocks and/or bonds. In a renewed loan a borrower could swap out securities in the basket of collateral, subject to the lender's approval.

9 Two types of overnight rates were reported_rates for "new" loans and "renewal rates." New loans were those beginning on a given day; renewal rates were for loans carried over from the previous day (that is, not called by the lender). Lenders allowing their loans to run another day were not obliged to accept the renewal rate but nearly always did.

10 General collateral repurchase agreements (repos) are short-term loans secured by collateral of a general type, such as Treasury or agency securities. See Federal Reserve Bank of New York; https://www.newyorkfed.org/markets/treasury-repo-reference-rates.

11 See Beckhart (1932, pp. 38-64). In 1914, the NYSE replaced "competitive bidding about a money post" (Beckhart, 1932, p. 43) with a "money desk." The "money clerk" at the desk took orders for new loans from brokers and offers of new funds from lenders and set a new loan rate "such as to bring about an equilibrium between supply and demand. However, the actual establishment of the rate does not always result simply from a balancing of forces of supply and demand. An equilibrium...is frequently reached through the control exercised by Stock Exchange officials over the supply of funds." Thus, if the amount of new funds demanded by brokers exceeded the amount offered, "the officials of the Stock Exchange Clearing Corporation might communicate with the larger banks in New York, requesting that funds be placed on the Exchange to meet the shortage in order to avoid an increase in rates" (p. 45).

12 Checks and other payment orders sent to the clearinghouse over the course of a day were cleared on the following day, in a session that began at 10 a.m. and ended at about 11:30 a.m., at which time a bank received its clearing balance. Soon after the founding of the Fed, banks began paying off clearinghouse net debits, or receiving net credits, with immediately effected transfers out of (into) their reserve accounts at the New York Fed (Spahr, 1926, pp. 393-404; and Meeker, 1930, pp. 287, 295, 362-401). Thus, a bank that made a new call money loan on Tuesday and called the loan as early as possible, on Wednesday morning, actually delivered the funds out of its Fed account around noon on Wednesday and was repaid principal and interest on Thursday.

13 Spahr (1926, pp. 208-09)

14 Banks maintain deposits with the Fed - "reserves" - to satisfy statutory reserve requirements and for making payments. Throughout the 1920s, such deposits were the only assets that a Fed member bank could use to satisfy its statutory reserve requirement. Banks also placed deposits with correspondent commercial banks for making payments, investing in securities markets, and other purposes (Watkins, 1929). Whereas the Fed did not pay interest on reserve deposits, interest was usually paid on interbank balances. The actual (or in some cases imputed) interest rates paid on interbank deposits in New York City were usually set by the New York Clearing House and adjusted with changes in the discount rate set by the New York Fed (New York Clearing House Association, 1920, p. 16).

15 Turner (1931, pp. 1-7). The Board ruled in 1928 and 1930 that loans of federal funds constituted borrowed money rather than deposits and thus were not subject to reserve requirements (Federal Reserve Bulletin, September 1928, p. 656; and Federal Reserve Bulletin, February 1930, p. 81).

16 Willis $(1957$, pp. 2, 5-7).

17 Board of Governors of the Federal Reserve System (1959, pp. 23-24).

18 New York Herald Tribune, April 5, 1928, p. 30.

19 Willis $(1957$, p. 3).

20 According to Willis (1970, p. 12, Table 1), in 1928, outstanding volumes of (i) brokers' loans ranged from $\$ 3,900$ to $\$ 5,100$ million for call loans and $\$ 390$ to $\$ 1,120$ million for time loans; (ii) bankers' acceptances ranged from $\$ 1,100$ to $\$ 1,300$ million; (iii) commercial paper totaled some $\$ 500$ million; and (iv) short-term government securities ranged from $\$ 2,500$ to $\$ 3,000$ million.

21 Turner (1931, p. 83). 


\section{Anbil, Carlson, Hanes, Wheelock}

$\underline{22}$ U.S. House of Representatives. "Testimony before the Banking Committee." 1926, p. 307.

$\underline{23}$ Transaction costs may have been higher for call money lending because it took time and effort to manage the security collateral (Griffiss, 1923, pp. 7, 16, 49). New York banks charged 1/2 percent to make call money loans for out-of-town banks (Turner, 1931, p. 68). That was bigger than the $1 / 4$ percent spread charged by federal funds brokers in the 1920s. Although so-called "money brokers" charged just 1/32 percent for call loans, according to Beckhart (1932, p. 49), "Money brokers do not...take care of the collateral; this is handled by the lending bank." Contemporaries generally described call money loans as practically risk-free, despite the possibility of a day-to-day drop in prices of collateral securities, because lenders were protected by "haircuts" (margins between current collateral prices and loan amounts). Moreover, at times when securities' prices were believed to be precariously high, as in the summer of 1929, haircuts were increased accordingly (Meeker, 1930, pp. 294, 297). Up to 1929, "even in the long memory of the oldest lending institutions in Wall Street, there is no record of any unpreventable loss by a lender on call loans made to a Stock Exchange member on listed collateral," and the 1929 crash itself took place "without the loss of a penny to a single lender" (Meeker, 1930, p. 298). On the other hand, White (1990) suggests that investors likely demanded higher rates on call money in 1928-29 because of their unwillingness to take possession of riskier collateral during this period.

$\underline{24}$ Eligible paper included bankers' acceptances, federal government debt, and certain types of bank loans-shortterm (original maturity 90 days or less) and "for producing, purchasing, carrying or marketing goods in one or more of the steps of the process of production, manufacture or distribution." A loan was not eligible if it financed purchases of stocks or bonds, or "for permanent or fixed investments of any kind, such as land, buildings or machinery" (Steiner, 1926).

$\underline{25}$ Board of Governors of the Federal Reserve System (1959, p. 28).

26 Dewey and Shugrue (1922) reported that investors viewed borrowing by banks in any form other than deposits as evidence of weakness.

27 Friedman and Schwartz (1963, pp. 254-65); and Board of Governors of the Federal Reserve System (1959, p. 98).

$\underline{28}$ The commercial paper market experienced various changes in subsequent decades. Nonbank financial companies_-such as the finance companies associated with automotive companies_found commercial paper to be an attractive source of funding and began to issue commercial paper (Hurley, 1977). Investors in commercial paper also began to shift, with nonbank investors such as insurance companies becoming increasingly important. Consequently, when the market revived in the 1950s, it was quite different than it had been in the 1920s.

$\underline{29}$ U.S. commercial banks with federal charters (i.e., national banks) were not permitted to issue bankers' acceptances before the Federal Reserve Act of 1913.

$\underline{30}$ For information on the bill buying rates of the New York Fed, see Board of Governors of the Federal Reserve System (1943a, pp. 443-45).

31 Bankers' acceptances played a key part in transmitting the financial crises in Germany and the United Kingdom in 1931 (Accominotti, 2012). The market never fully recovered; as other money markets expanded in the 1950s, the bankers' acceptance market remained a niche market.

32 See the following New York Times articles: "Pegged Call-Money Rate of 1\% is Ended." April 14, 1935; "Money Rates Stay 5th Month at Lows." October 1, 1935; "Call Money Rates Raised by Banks." October 30, 1935; "Changes in Money Rates." October 31, 1935; and "Banks Here Double Call-Money Rate." January 23, 1936. Wall Street Journal articles include the following: "Money Rates Firm as Bankers Seek 'Living Wage'." October 30, 1935; and "Call and Time Money Rate Advance of 1/4\% Expected Next Week." May 9, 1936.

33 Wall Street Journal. "Call Loan Market is Now Pegged at New 3/4\% Rate." November 7, 1935, p. 9.

34 See, for example, New York Herald Tribune. "Comment in Wall Street." April 11, 1935, p. 25; and New York Times. "Loans to Brokers Down \$64,000,000." August 30, 1935.

35 Wall Street Journal. “Money Rates." February 24, 1934, p. 4.

36 Wall Street Journal. “Call Loan Market now Pegged at New 3/4\% Rate.” November 7, 1935.

$\underline{37}$ New York Herald Tribune. "Rise in Reserve Needs to Alter Money Rates." January 10, 1937, p. C1.

$\underline{38}$ See the following articles: Wall Street Journal. "Higher Rate on Federal Funds Are Likely." March 12, 1937, p. 1; New York Herald Tribune. "Comment in Wall Street." March 13, 1937, p. 23; Wall Street Journal. "Commercial Borrowing 
Anbil, Carlson, Hanes, Wheelock

Gains Expand." March 16, 1937, p. 1; New York Times. "Higher Reserves Are Met by Banks." May 2, 1937; and New York Times. "Topics in Wall Street." May 4, 1937.

39 See the following articles: Wall Street Journal. "Member Banks' Excess Reserves Touch New Low." August 6, 1937, p. 9; and New York Herald Tribune. “Comment in Wall Street." August 11, 1937, p. 27.

40 See New York Times. “Bank Credit Here Continues to Rise." December 17, 1937; and New York Times. "Bank Credit Here Gains \$465,000,000." June 10, 1938.

$\underline{41}$ Board of Governors of the Federal Reserve System (1959, p. 70).

$\underline{42}$ Interestingly, rates on some other money market instruments, in particular commercial paper and bankers' acceptances, also rose around this time.

$\underline{43}$ Hanes $(2006,2019)$ studies the behavior of overnight rates in the 1930s in terms of modern models and provides details about the timing of Fed and Treasury policies, changes in reserve supply, and interest rate movements in the 1930s.

$\underline{44}$ After the war, loans to securities dealers were still referred to as call money but "in current practice such loans are rarely called" (Miller, 1952, p. 31). Call money loans had become relationship loans between a dealer and a bank, and "the formal arrangements of an impersonal market no longer exist" (p.27). The call money desk on the NYSE floor was eliminated in 1946.

$\underline{45}$ Friedman and Schwartz (1963, pp. 562-63, 623-24).

46 Federal Reserve Bank of New York Monthly Review (September 1942, p. 67).

47 Board of Governors of the Federal Reserve System (1943b, p. 108).

$\underline{48}$ For information about the Fed's Overnight Reverse Repurchase Agreement Facility, see https://www.federalreserve.gov/newsevents/pressreleases/monetary20200615b.htm.

$\underline{49}$ Federal Reserve Bank of New York Monthly Review (August 1947, p. 77).

50 We located only two newspaper reports of trading between October 1942 and May 1945 (New York Times. "Excess Reserves at a 5-Year Low." October 2, 1942, p. 33; and New York Times. "Member Banks Again Show Excess Reserves." May 19, 1944, p. 24).

51 Federal Reserve Bank of New York Monthly Review (March 1950, pp. 27-28).

$\underline{52}$ Board of Governors of the Federal Reserve System (1959, pp. 17, 46, 48). The timing difference created opportunities for arbitrage and regulatory avoidance (see, e.g., Coats, 1981). It did not disappear until 1981, when the New York Fed agreed to integrate the New York Clearing House interbank payments system (which had become "CHIPS") into the Fed's transfer system (which had become "Fedwire") (Stigum, 1990, pp. 206, 894, 898).

$\underline{53}$ Federal Reserve Bank of New York Monthly Review (March 1950, p. 29); and Board of Governors of the Federal Reserve System (1959, p. 98). The federal funds rate did not rise above the discount rate until October 1964. According to Stigum (1990, pp. 544-45), this was because a stigma had developed against borrowing federal funds at rates above the discount rate: "[B]ankers feared that any bank that was willing to pay more than the discount rate for Fed funds would be subject to the accusation that for some reason it could not borrow at the window.... Finally, in 1964, Morgan [the New York commercial bank Morgan Guaranty Trust Company] decided that if any bank could get away with paying more than the discount rate for Fed funds, it could."

$\underline{54}$ Willis (1970, pp. 54-55).

$\underline{55}$ Board of Governors of the Federal Reserve System (1959, p. 93).

$\underline{56}$ Minsky (1957, p. 175).

57 Board of Governors of the Federal Reserve System (1959, pp. 5-6). See also Roosa (1956) regarding the linkages between the federal funds market and the government securities dealers.

$\underline{58}$ Willis (1970, p. 56).

$\underline{59}$ Shown in Figure $\mathrm{A} 1$ of the appendix, the volatility of our new series on the funds rate is similar to the Board's series in 1954. 


\section{Anbil, Carlson, Hanes, Wheelock}

$\underline{60}$ Federal funds rate quotations and other market information were also occasionally published in the New York Times.

61 See FRED ${ }^{\circledR}$, Federal Reserve Bank of St. Louis; https://fred.stlouisfed.org/categories/33951.

62 The New York Herald Tribune (p. 30) explained that "For the nominal charge of one-fourth of 1 percent...[dealers] locate banks which are in need [of funds]. Conversely they locate prospective borrowers for banks which are faced with a plethora of excess deposits at the Reserve Bank... Thus the rate was 33/4 bid, 4 percent asked, yesterday [April 4]. The discount house purchases the funds at 33/4 and sells them at 4 percent." The explanation of the funds rate in the New York Herald Tribune is consistent with Turner's $(1931$, p. 8) following description of the market: "Federal funds are usually quoted with a quarter of a point spread in rates; hence, when 'Funds are 33/4 - 4[\%]' the bid rate is $33 / 4 \%$ and the asked rate is $4 \%$." Turner also reports that dealers in federal funds typically earned a quarter point spread: "[T] hey would buy from the bank having a surplus [of funds] at say $3 \frac{1}{2} \%$ and sell to the bank that was short in its reserves at 33/4\%" (p. 21) .

63 January 25, 1929; November 4, 1929; February 21, 1930; and April 20, 1931.

64 In the accompanying dataset, observations for some dates are missing because either we were unable to locate the edition of the New York Herald Tribune in which the quotes appeared or the reported rates were illegible. Implausible observations include February 6, 1931, and June 20, 1931.

$\underline{65}$ From June 1932 to February 1933, the Wall Street Journal reported rates in a manner that looks like bid and asked rates, such as "Federal funds 1/2\% @ 3/4\% [Wednesday], against 3/4\% @ 1\% Tuesday."

$\underline{66}$ New York Herald Tribune. “Excess Reserves of Local Banks Reduced to $\$ 150,000,000$ Level." May 4, 1937, p. 31.

67 We recorded federal funds rate quotation from every issue of the New York Herald Tribune from April 5, 1928, through March 1, 1934, that we could locate, but because the reported rate rarely changed, we checked every third issue to verify the rate, focusing on periods when the rate was more likely to have changed. The rate reported in the Wall Street Journal was static from March 1934 through the end of 1944. We checked every third issue to verify the constant rate, focusing on periods when the rate was more likely to have changed.

68 From May 1937 until mid-July 1944, the Wall Street Journal reported "Federal funds offered at 1/4 of 1\%." On July 18,1944 , the Wall Street Journal reported "Federal funds offered at 1/4 o [sic] 1\%" and on the next day "Federal funds offered at 1/4 to 1\%." That phrase was repeated until May 1945. We believe that the shift from "of," which would reflect a point rate, to "to," which would reflect a range, is a typo, especially since there were no changes in any other money markets.

$\underline{69}$ Note that borrowed reserves refer to the outstanding stock of Fed discount window loans and are referred to as "bills discounted" in the source.

\section{REFERENCES}

Accominotti, Olivier. "London Merchant Banks, the Central European Panic, and the Sterling Crisis of 1931." Journal of Economic History, 2012, 72(1), pp. 1-43; https://doi.org/10.1017/S0022050711002427.

Beckhart, Benjamin H. The New York Money Market, Volume III: Uses of Funds. New York: Columbia University Press, 1932; https://doi.org/10.7312/beck93862.

Board of Governors of the Federal Reserve System. Banking and Monetary Statistics, 1914-1941. Washington, D.C., 1943a.

Board of Governors of the Federal Reserve System. Twenty-Ninth Annual Report of the Board of Governors of the Federal Reserve System, 1942. Washington, D.C., 1943b.

Board of Governors of the Federal Reserve System. The Federal Funds Market - A Study by a Federal Reserve System Committee. Washington D.C., 1959.

Board of Governors of the Federal Reserve System. Banking and Monetary Statistics, 1941-1970. Washington D.C., 1976.

Bordo, Michael and Sinha, Arunima. "A Lesson from the Great Depression that the Fed Might have Learned: A Comparison of the 1932 Open Market Purchases with Quantitative Easing." NBER Working Paper 22581, National Bureau of Economic Research, 2016; https://doi.org/10.3386/w22581. 
Burgess, W. Randolph. The Reserve Banks and the Money Market. New York: Harper, 1936.

Chandler, Lester V. Benjamin Strong, Central Banker. Washington, D.C.: The Brookings Institution, 1958.

Coats, Warren L. "The Weekend Eurodollar Game." Journal of Finance, June 1981, 36(3), pp. 649-59; https://doi.org/10.1111/j.1540-6261.1981.tb00650.x.

Dewey, Davis and Shugrue, Martin. Banking and Credit. New York: The Ronald Press Company, 1922.

Ennis, Huberto M. and Keister, Todd. "Understanding Monetary Policy Implementation." Federal Reserve Bank of Richmond Economic Quarterly, Summer 2008, 94(3), pp. 235-63.

Federal Reserve Bank of New York. "Federal Funds." Federal Reserve Bank of New York Monthly Review, March 1950, pp. 28-30.

Fohlin, Caroline. "Did the Founding of the Fed Stabilize the Overnight Funding Market? New Evidence from Daily Call Money Rates, 1900-33." Working paper, 2020.

Friedman, Milton and Schwartz, Anna J. A Monetary History of the United States 1867-1960. Princeton: Princeton University Press, 1963.

Griffiss, Bartow. “The New York Call Money Market." Johns Hopkins University Dissertation, 1923.

Hanes, Christopher. "The Liquidity Trap and U.S. Interest Rates in the 1930s." Journal of Money, Credit and Banking, February 2006, 38(1), pp. 163-94; https://doi.org/10.1353/mcb.2006.0017.

Hanes, Christopher. "Quantitative Easing in the 1930s." Journal of Money, Credit and Banking, August 2019, 51(5), pp. 1169-207; https://doi.org/10.1111/jmcb.12589.

Hsieh, Chang-Tai and Romer, Christina D. "Was the Federal Reserve Constrained by the Gold Standard during the Great Depression? Evidence from the 1932 Open Market Purchase Program." Journal of Economic History, March 2006, 66(1), pp. 140-76; https://doi.org/10.1017/S0022050706000064.

Hurley, Evelyn. “The Commercial Paper Market." Federal Reserve Bulletin, June 1977, pp. 525-36.

Kliesen, Kevin L. and Wheelock, David C. "Managing a New Policy Framework: Paul Volcker, the St. Louis Fed, and the 1979-82 War on Inflation." Federal Reserve Bank of St. Louis Review, 2021, 103(1), pp. 71-97.

Meek, Paul. "Discount Policy and Open Market Operations," in Reappraisal of the Federal Reserve Discount Mechanism. Washington, D.C.: Board of Governors of the Federal Reserve System, 1972.

Meeker, J. Edward. The Work of the Stock Exchange, revised edition. New York: Ronald Press Company, 1930.

Meltzer, Allan H. A History of the Federal Reserve, Volume 1: 1913-1951. Chicago: University of Chicago Press, 2003; https://doi.org/10.7208/chicago/9780226519982.001.0001.

Miller, Stanley L. "Financing Security Brokers and Dealers," in Money Market Essays. New York: Federal Reserve Bank of New York, March 1952, pp. 27-33.

Minsky, Hyman P. "Central Banking and Money Market Changes." Quarterly Journal of Economics, May 1957, 71(2), pp. 171-87; https://doi.org/10.2307/1883812.

Myers, Margaret G. The New York Money Market, Volume I: Origins and Development. New York: Columbia University Press, 1931; https://doi.org/10.7312/myer93866.

New York Clearing House Association. Constitution of the New York Clearing House Association. Also Clearinghouse Rules, Scale of Fines, Collection Charges, and Holiday Laws of New York State. New York: New York Clearing House Association, 1920.

Odell, Kerry A. and Weidenmier, Marc D. "Real Shock, Monetary Aftershock: The 1906 San Francisco Earthquake and the Panic of 1907." Journal of Economic History, December 2004, 64(4), pp. 1002-27; https://doi.org/10.1017/S0022050704043062.

Officer, Lawrence H. "The Remarkable Efficiency of the Dollar-Sterling Gold Standard, 1890-1906." Journal of Economic History, March 1989, 49(1), pp. 1-41; https://doi.org/10.1017/S0022050700007324.

Poole, William. "Commercial Bank Reserve Management in a Stochastic Model: Implications for Monetary Policy." Journal of Finance, December 1968, 23(5), pp. 769-91; https://doi.org/10.1111/j.1540-6261.1968.tb00316.x. 


\section{Anbil, Carlson, Hanes, Wheelock}

Rappoport, Peter and White, Eugene N. "Was There a Bubble in the 1929 Stock Market?" Journal of Economic History, September 1993, 53(3), pp. 549-74; https://doi.org/10.1017/S0022050700013486.

Riefler, Winfield W. Money Rates and Money Markets in the United States. New York: Harper, 1930.

Roosa, Robert V. Federal Reserve Operations in the Money and Government Securities Markets. New York: Federal Reserve Bank of New York, 1956.

Spahr, Walter Earl. The Clearing and Collection of Checks. New York: Bankers Publishing Company, 1926.

Steiner, W. H. "Paper Eligible for Rediscount at Federal Reserve Banks: Theories Underlying Federal Reserve Board Rulings." Journal of Political Economy, June 1926, 34(3), pp. 327-48; https://doi.org/10.1086/253765.

Stigum, Marcia L. The Money Market, Third Edition. Chicago: Irwin, 1990.

Sylla, Richard. "Federal Policy, Banking Market Structure, and Capital Mobilization in the United States, 1863-1913." Journal of Economic History, December 1969, 29(4), pp. 657-86; https://doi.org/10.1017/S002205070007193X.

Turner, Bernice. The Federal Fund Market. New York: Prentice-Hall, 1931.

Turner, Robert C. Member Bank Borrowing. Columbus, OH: Ohio State University Press, 1938.

Watkins, Leonard. Bankers Balances. Chicago: A.W. Shaw Company, 1929.

White, Eugene. "The Stock Market Boom and Crash of 1929 Revisited." Journal of Economic Perspectives, 1990, 4(2), pp. 67-83; https://doi.org/10.1257/jep.4.2.67.

Whitesell, William. "Interest Rate Corridors and Reserves." Journal of Monetary Economics, September 2006, 53(6), pp. 1177-95; https://doi.org/10.1016/j.jmoneco.2005.03.013.

Whittlesby, Charles R. Bank Liquidity and the War. New York: National Bureau of Economic Research, 1945.

Willis, Parker B. The Federal Funds Market: Its Origins and Development. Boston: Federal Reserve Bank of Boston, 1957; reprinted and extended, 1970. 